\title{
Recent Trends in Neuro marketing - An Exploratory Study
}

\author{
Dsouza Prima Frederick \\ Research Scholar, College of Management \& Commerce, Srinivas University, \\ Mangalore- 575001, India
}

Orcid ID: 0000-0003-2568-5619; Email ID: primadsouza.cmc@ srinivasuniversity.edu.in

Area of the Paper: Business Management.

Type of the Paper: Conceptual Paper.

Type of Review: Peer Reviewed as per $|\mathrm{C}| \mathrm{O}|\mathrm{P}| \mathrm{E} \mid$ guidance.

Indexed In: OpenAIRE.

DOI: https://doi.org/10.5281/zenodo.5978946

Google Scholar Citation: IJCSBE

\section{How to Cite this Paper:}

Dsouza, Prima Frederick, (2022). Recent Trends in Neuro marketing - An Exploratory Study. International Journal of Case Studies in Business, IT, and Education (IJCSBE), 6(1), 38-60. DOI: https://doi.org/10.5281/zenodo.5978946

International Journal of Case Studies in Business, IT and Education (IJCSBE)

A Refereed International Journal of Srinivas University, India.

Crossref DOI : https://doi.org/10.47992/IJCSBE.2581.6942.0148

(C) With Authors.

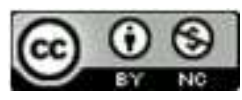

This work is licensed under a Creative Commons Attribution Non-Commercial 4.0 International License subject to proper citation to the publication source of the work.

Disclaimer: The scholarly papers as reviewed and published by the Srinivas Publications (S.P.), India are the views and opinions of their respective authors and are not the views or opinions of the S.P. The S.P. disclaims of any harm or loss caused due to the published content to any party. 


\title{
Recent Trends in Neuro marketing - An Exploratory Study
}

\author{
Dsouza Prima Frederick \\ Research Scholar, College of Management \& Commerce, Srinivas University, \\ Mangalore- 575001, India
}

Orcid ID: 0000-0003-2568-5619; Email ID: primadsouza.cmc@ srinivasuniversity.edu.in

\begin{abstract}
Purpose: The concept of neuro-marketing is explored as an emerging economic approach that originated from human brain research and traditional marketing facts. The core idea of the paper is to understand the concept of Neuromarketing and its influence on customers' decisionmaking process.
\end{abstract}

Design: The benefits of various neuromarketing tactics on various market input devices are studied in the paper. From available literature and research studies, the influence of neuromarketing's various techniques and procedures on verifiable marketing success is been highlighted.

Findings: Neuromarketing concept has gain lot of importance in recent years. It has contributed in the various fields of marketing such as framing marketing strategies, selection of brand, consumer behaviour, advertising, ethical concerns and decision-making. The study highlights the importance of neuromarketing principles and concepts for engaging neuroscience in the field of marketing and understanding consumer behaviour which could help in planning new marketing strategies based on neuroscience.

Originality: The impact of sensory aspects on a customer's perception and conscious or subconscious purchasing choice is highlighted in this study. It also addresses the ethical problems that have been raised concerning neuromarketing. In this study, the benefits, limitations, ethical difficulties, and future potential of neuromarketing are discussed.

Value: A neuromarketing study will help the companies compete for market leadership, increase customer base and convert them into loyal consumers. It will help to determine what the customer wants, what services he likes, and how to draw the consumer's attention. Marketers can understand customer behaviour, including how it reacts to a company's advertising, brand, and product quality. Neuro-marketing can help a marketer to increase their turnover.

Type of Paper: Conceptual Paper.

Keywords: Neuro-marketing concept, Neuro-marketing techniques, Benefits, Impact, Ethical Issues.

\section{INTRODUCTION :}

Neuromarketing is technique used in marketing that tries to build a strong relationship between the customer and the product or services by focussing into the emotional feeling and subconscious mind of an individual. It is considered as an interdisciplinary discipline approach as it encompasses many other fields like psychology, sociology, marketing and neuroscience. It considers the analysis of the emotional reactions or responses and Individual's cognitive behaviour to diverse marketing strategies [1]. The word neuro-culture refers to the domains of neuro-biology. It is the birthplace of emerging scientific subjects such as neuroethology and neuro-philosophy, which combine neuroscience with other scientific fields [2]. The word neuromarketing was coined by market research firms in 2002. Bright House and Sales Brain, two market research firms based in the United States, pioneered the use of material information from cognition in market research. In the field of market research this neuroscience has played a vital role as it analyses consumers behaviour. Montague of Baylor College of Medicine in the year 2004, used the fMRI technology to scan a person's brain when they drink carbonated drinks 
like Pepsi or Coca-Cola. It was seen that neural activity had a change when the person consuming was aware of the brand name of the drink. When the person has their favourite brand drink, the frontal cortex of the brain had a stimulated activity [3]. This part of the brain is engaged in actions such as paying attention to short-term memory, decision-making and detailing of the activities. This experiment test is the first time proved the importance of neuromarketing as a legitimate marketing strategy and the function of the brain's emotional link with brand popularity.

\section{RELATED WORKS :}

Neuromarketing concept has gained a crucial importance in today's competitive business world. Of late, many businesses have understood the importance of analysing consumer mindset for its long-term survival. Many researchers have made studies in this concept and how this study give fruitful results to organisations. Below Table 1 shows scholarly contribution about neuromarketing.

Table1: Exhibits scholarly contribution in Neuromarketing

\begin{tabular}{|c|c|c|}
\hline Sl. No. & Contribution & $\begin{array}{c}\text { Reference } \\
\text { Number }\end{array}$ \\
\hline 1. & $\begin{array}{l}\text { Neurologists can make a massive input to the ethical argument over invasive } \\
\text { neuromarketing and consumer neuroscience technologies. The biological and } \\
\text { behavioural responses of subjects if analysed, the results could help the } \\
\text { marketers to design effective advertising tactics, moreover, the results which } \\
\text { exhibits a unique consumer vulnerability can be used for target-based } \\
\text { marketing. }\end{array}$ & {$[2]$} \\
\hline 2. & $\begin{array}{l}\text { Neuroscience is increasingly being explored as a viable foundation for future } \\
\text { management and commercial strategies. Neuromarketing is a relatively new } \\
\text { form of study which includes consumer research that uses neuroscience to } \\
\text { marketing by using brain imaging or measuring technologies to predict } \\
\text { customer reactions to products, packaging, or advertising. The finding is } \\
\text { paradoxical in that it requires the creation of a difference between what seems } \\
\text { to be the case - customers' descriptions of why they prefer some items over } \\
\text { others - and what can be demonstrated to be the case as a consequence of the } \\
\text { technology's application - the veiled or obscured reality. }\end{array}$ & [3] \\
\hline 3. & $\begin{array}{l}\text { Neuromarketing offers advantage with the most recent advances in brain } \\
\text { scanning to gain a better understanding of the psychological processes that } \\
\text { drive individual purchase choices. Data from } 111 \text { marketing academics, } 52 \\
\text { neurologists, and } 56 \text { marketing professionals was statistically analysed. } \\
\text { Neuromarketing, according to all participants, is not a deceptive method of } \\
\text { selling superfluous products and services. Three characteristics were } \\
\text { identified as the most significant features of neuromarketing by the three } \\
\text { groups of participants: interest and involvement, awareness and knowledge, } \\
\text { and ethics. }\end{array}$ & {$[4]$} \\
\hline 4. & $\begin{array}{l}\text { Consumer neuroscience focuses on issues of consumption and marketing } \\
\text { using neuroscientific approaches and insights. Consumer behaviour and } \\
\text { marketing research has always seen the human body as a "black box" that } \\
\text { cannot be analysed directly or biologically. Whilst consumer neuroscience is } \\
\text { still in its infancy, it represents a step forward in the direction of more } \\
\text { extensive testing and theory growth. The study will help the marketer to } \\
\text { better understand their consumer mindset. }\end{array}$ & [7] \\
\hline 5. & $\begin{array}{l}\text { Neuromarketing is a new area that combines consumer behaviour research } \\
\text { with neurological research. When it originally debuted in 2002, it was } \\
\text { controversial, but the area is quickly gaining legitimacy and popularity } \\
\text { among advertising and marketing experts. Over } 400 \text { billion dollars is spent } \\
\text { on marketing campaigns each year. Traditional approaches for assessing and } \\
\text { forecasting the impact of such investments, on the other hand, have mostly } \\
\text { failed since they rely on consumers' willingness and ability to explain how }\end{array}$ & [8] \\
\hline
\end{tabular}




\begin{tabular}{|c|c|c|}
\hline & $\begin{array}{l}\text { they feel when introduced to advertisements. Neuromarketing uses cutting- } \\
\text { edge techniques to directly probe people's thoughts without having them to } \\
\text { engage in complex cognitive or consciousness activities. }\end{array}$ & \\
\hline 6. & $\begin{array}{l}\text { Consumer neuroscience, often known as neuromarketing, is a subfield of } \\
\text { neuroeconomics that uses methodologies and insights from brain research to } \\
\text { solve marketing-related challenges. The research contributes to a better } \\
\text { knowledge of the consumer brain and its positive influence on marketing-mix } \\
\text { instruments including product, pricing, communication, and distribution } \\
\text { strategies, as well as brand research. }\end{array}$ & [13] \\
\hline 7. & $\begin{array}{l}\text { The brain activity resulting from watching an advertising is tracked and } \\
\text { quantified using neuroimaging techniques such as functional magnetic } \\
\text { resonance imaging (fMRI) and electroencephalography to assess the success } \\
\text { of these techniques (EEG). In most neuromarketing research, brand } \\
\text { awareness or brand preferences are used to compare product preferences. } \\
\text { Measures like product preference for a certain commercial might be difficult } \\
\text { to evaluate in typical marketing research since consumers may have a } \\
\text { prejudice. Brand familiarity and product choice, on the other hand, have been } \\
\text { linked to brain activity. However, because of the potential ethical } \\
\text { implications of developing advertising to purposely elicit certain } \\
\text { neurological effects, the area of neuromarketing is still viewed with } \\
\text { scepticism by consumer nongovernmental organizations and many } \\
\text { researchers. }\end{array}$ & [22] \\
\hline
\end{tabular}

\section{RESEARCH GAP :}

Marketing is not only about manufacturing like traditional concept. In the recent past, to market a product the marketers must make an attempt to influence the customers through an emotional connect. Marketers need to develop unique strategies to create and retain customers. Moreover, it is essential to understand and know the factors influencing the judgement of the people's choice, as a marketer invests his valuable resource in marketing. Of late, the concepts such as neuroimaging and neuromarketing have revolutionized as a realistic option for modifying the future generation of smart customers and the increasingly competitive consumer market. The neuromarketing approach is the most up-to-date and sophisticated instrument utilized by marketing experts to investigate and comprehend customer attitudes and behaviours [3]. Neuromarketing employs cutting-edge brain-scanning technology to decipher the subtleties of the customer's psychological decision-making process. [4]. Subconscious responses of the customers towards the marketing stimuli are observed via brainwave analysis [5-9]. What aspects of advertisement influences the customer's choice can be identified using Neuromarketing [10][11][12]. This can help with visual and audio feature selection and timing for a successful commercial [11]. This will undoubtedly aid in the design of brands, brand research, and the impact on the customer's decision-making process [13]. Neuromarketing provides new avenues for studying and identifying the causes of hedonic shopping disorders, as well as the potential for its application in successful advertising. [10][11][14][15][17][18]. Therefore, there is a need to understand and identify the unique approach of neuromarketing that can obtain the information above and beyond the level of human intellect and perception affecting the turnover of the company in a macro way because purchasing activity done by customers is a result of the influence of one's subconscious mind.

\section{RESEARCH AGENDA :}

The study intends to answer the following research agenda:

1. What is the relevance of neuromarketing?

2. What is the implication of neuro study in the field of marketing?

3. Are there any benefits of using neuromarketing?

4. Are there any constraints in using neuromarketing?

5. Are there any ethical issues in neuromarketing?

6. What are the challenges and future possibilities of neuromarketing? 


\section{OBJECTIVES OF THE STUDY :}

(1) To analyze the relevance of neuromarketing.

(2) To assess the implication of neuro study in the field of marketing.

(3) To understand the various neuromarketing benefits.

(4) To determine the limitations and impact of neuromarketing

(5) To identify the ethical issues in neuromarketing.

(6) To evaluate the challenges and future possibilities of neuromarketing.

\section{MATERIAL AND METHODOLOGY :}

The benefits of various neuromarketing strategies on various market input instruments are thoroughly examined in this critical review. The impact of neuromarketing's varied strategies and processes on verified marketing success stories is extracted from the existing literature and research studies. Neuromarketing's benefits, limits, ethical issues, and future possibilities are been highlighted in this study.

\section{FUNCTION OF THE HUMAN BRAIN :}

The brain is a three-pound organ that governs all physical activities of a Human. Creativity, Intelligence, memory, and emotions are all controlled by it. Smell, Sight, taste, touch, and hearing are the five senses through which the brain gets information. It accepts and processes the data before storing it in our memory for later purposes. The cerebrum is the largest and most visible region of the brain. The cerebrum is divided into two hemispheres. The frontal, parietal, temporal, and occipital lobes are found in each of the hemispheres. Planning, Behaviour, judgment, emotions, and problem-solving are all influenced by the frontal lobe. Hearing, Vision, sensory, motor, and memory information are all interpreted by the parietal lobe. The temporal lobe is responsible for language comprehension and memory.

\section{Neuronal Coding and Memory:}

Encoding, storing, and decoding are the three operations that makeup memory (Figure 1). Various parts of the human brain are engaged which depends on the nature of memory. The memory of the human brain can be for short term or long term. The Short term memory last for sixty seconds which is stored on prefrontal cortex. Long term memory is stored in which is passed by temporal lobe's hippocampus. Glial cells and Nerve cells (neurons) make up the average brain. Chemical and Electrical impulses are the primary means by which the neuron acts. It communicates with each other through microscopic gaps known as a synapse. Dendrites are the many arms of a neuron. They function as antennas like taking up signals from other nerve cells. Encoding is the process of converting information received by the brain into codes and storing them in memory. Decoding is used to retrieve information from memory. The human brain has code called as neural code similar to a computer which as binary code. Neuromarketing alters the neural code of a person's brain to influence a person's purchasing decision by hypnotizing.

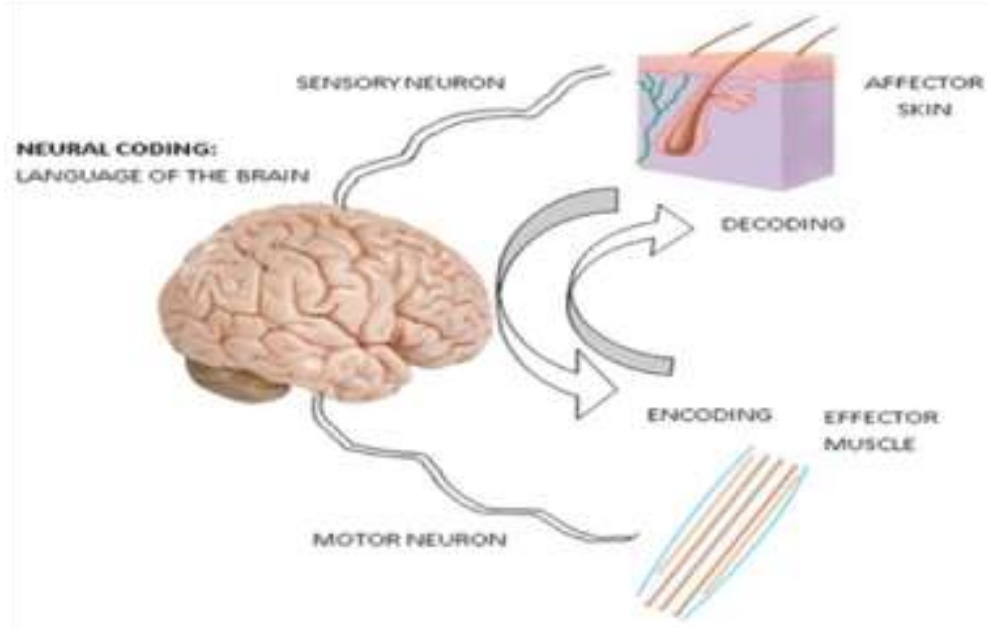

Fig. 1: Shows neural coding of a Human brain [72]. 


\section{NEUROMARKETING TECHNIQUES :}

The various techniques of neuromarketing are as follows:

\subsection{Outside Reflex}

Body language, facial coding, eye contact, and empathic design are all popular outer reflex methods. They gather information which are made up of traditional ways for the brain. As they perceive they get originated in the human brain. Emotional responses like goosebumps and sweat is the outside reflexes which are measured with lie detector [19].

\section{(1) Body Language}

It is an important part of communication. Body language like an fMRI scanner provides a window into the brain's emotions. Communicational signals and Nonverbal emotions are communicated through muscular contraction and relaxation in body language. It also involves bodily motions, gestures, and posture both intentional and unconscious.

\section{(2) Empathic Design}

It is a popular way of analyzing human beings without the use of any technology. Without the customer's awareness, sensitive observations are conducted on their everyday routine [20]. A careful observation of a test person's use of a product in its natural setting is made. The direct-marketing principle [19][20] describes the practice of gathering information rather than asking a person and utilizing the knowledge in marketing.

\section{(3) Facial Coding}

It is the process of recognizing and categorizing facial expressions that are connected with human emotions. Seven main human emotions are associated with a total of twenty-four muscle action combinations. Dan Hill, a top face coding researcher, conducts ground-breaking facial coding research [72]. Facial expression patterns and Specific stimuli are recognized, decoded, and used in marketing. Below Table 2 describes an overview of the use of facial coding in neuromarketing and its measures, usage, benefits, and limitation.

Table 2: Exhibits the information of the use of facial coding in neuromarketing research

\begin{tabular}{|c|c|}
\hline Measures & Usage in testing \\
\hline $\begin{array}{l}\text { - non-conscious reactions } \\
\text { - } 43 \text { facial muscles } \\
\text { - Emotions like smile, anger, envy, dislike, fear, } \\
\text { surprise, sadness }\end{array}$ & $\begin{array}{l}\text { - Commercial Ads } \\
\text { - Small Movie trailers }\end{array}$ \\
\hline Benefits & Limitation \\
\hline $\begin{array}{l}\text { - Information of impulsive facial expressions } \\
\text { - Gives present information }\end{array}$ & $\begin{array}{l}\text { - preconception in determining whether an action } \\
\text { has transpired or it will come across the least } \\
\text { requirements for coding }\end{array}$ \\
\hline
\end{tabular}

\section{(4) Eye Tracking}

The subconscious brain's reactivity to stimulation is shown by eye-tracking. This procedure is dependable. The data gathered by eye tracking is utilized to create successful advertising and websites. It allows market analysts to follow the finer points of a customer's interest and preference. It is also possible to specify the order in which preferences are chosen.

\section{(5) Input-/Output Models}

This strategy examines the pattern of responses to a certain stimulus to gain access to brain activity. The brain is treated as a black box in the Input/Output Model. This strategy is based on the idea that each marketing stimulus has a measurable result [19].

\subsection{Inside Reflexes:}

The inner reflex method allows a glimpse into the brain. It is accomplished by the use of a variety of procedures including brain scans. In terms of applicability inside reflexes differ from the input-output paradigm. It has the most influence in advertising when it comes to packaging. During the duration of advertising, it influences the emotional attachment of a person to the product and creates a psychological effect on a potential consumer. 
(1) Electroencephalography

Electroencephalography (EEG) is an electrical picture of the activity of a brain. Brain location can be detected by changes in electrical field which is used in this method [5-8] [21-22].

Electroencephalography creates a data record of the electrical signals of the activity of the brain using electrodes [5][8][19][22]. The electrodes can be worn on the head. It has a forty-minute recording capacity. Neurons are the cells that respond to stimuli in the brain. There are billions of synapses in the brain that are involved in cognition [8]. A helmet or hat with electrodes is placed on the head of the individual which is followed by a display of products and services. Brain activity can be used to measure the relative attraction of a product to a buyer [8][19]. Because of its millisecond temporal resolution, EEG can detect brief bursts of brain activity [5][21]. EEG measurement equipment is light and portable [22]. The most significant downside of EEG is noise or unwanted electrical activity from the brain. [19]. Another issue is the lack of accurate spatial resolution (approximately one centimetre). This problem can be solved by placing more electrodes on the skull [5][8][21]. Below Table 3 describes an overview of EEG in neuromarketing and its measures, usage, benefits, and limitation.

Table 3: Overview of EEG in neuromarketing research.

\begin{tabular}{|c|c|}
\hline Measures & Usage in testing \\
\hline $\begin{array}{l}\text { - Attention } \\
\text { - monotony } \\
\text { - enthusiasm } \\
\text { - emotional } \\
\text { - reasoning } \\
\text { - appreciation } \\
\text { - Positive approach } \\
\text { - withdrawal }\end{array}$ & $\begin{array}{l}\text { - Commercial Ads } \\
\text { - Small movie trailers } \\
\text { - Recognizing the crucial flashes of an } \\
\text { commercials } \\
\text { - Website's design and accessibility } \\
\text { - Store Ambience and experience } \\
\text { - Commercial taglines }\end{array}$ \\
\hline Benefits & Limitation \\
\hline $\begin{array}{l}\text { - simple to use in comparison to fMRI technique } \\
\text { [75] } \\
\text { - able to measure the disparities of the activity of } \\
\text { the human brain by knowing the frequency of } \\
\text { electrical activity [76], along with neural action } \\
\text { in the human brain [77] } \\
\text { - temporal resolution is presented in precise } \\
\text { helping marketers understand the brain activity } \\
\text { associated to changing stimuli [78] } \\
\text { - left and right hemispheres of the brain can be } \\
\text { compared [79], determine the approach viz (left- } \\
\text { hemisphere of brain is identified as dominance - } \\
\text { optimistic emotional retorts) or withdrawal } \\
\text { approach like (right-hemisphere of the brain is } \\
\text { identified as dominance - undesirable emotional } \\
\text { retort) [78] } \\
\text { - shows the correlation among personality traits } \\
\text { and EEG asymmetry [79] } \\
\text { - accessible in Statistical Software Packages } \\
\text { (SSP) [79] } \\
\text { - low cost of analysis; low cost of equipment; fast } \\
\text { data analysis [79][80][81] } \\
\text { - non- aggressive method } \\
\text { - portable } \\
\text { - effective measure for intellectual information } \\
\text { [76] }\end{array}$ & $\begin{array}{l}\text { - it is difficult to know the location for signal } \\
\text { which is recorded as the electric conductivity on } \\
\text { every person may differ [80][82] } \\
\text { - low 3-D resolution, it considers only cortex } \\
\text { activity from superficial layers [82] } \\
\text { - non-scalable [75] } \\
\text { - optimistic or negative emotion can be } \\
\text { determined [75] } \\
\text { - reasonable to high complexity [79] } \\
\text { - outcomes are prejudiced by experimental } \\
\text { settings [76] and by stirring artifacts }\end{array}$ \\
\hline
\end{tabular}




\section{(2) Functional Magnetic Resonance Imaging (fMRI)}

Anatomic structure of the brain and blood flow regulation is studied in this method [19]. MRI scan is performed to know the blood oxygen levels [5]. It is indicated by an increase in neuronal activity in that location. fMRI is a neuromarketing technique for examining changes in brain activity between various brain areas [19][22][24]. Different magnetic waves are produced by oxygenated and deoxygenated blood. Signals can be used to identify this discrepancy [21]. Initially, a resting-state fMRI brain scan with no stimuli was utilized as a baseline [25]. The advertising stimulation increases the flow of oxygenated blood to certain brain areas [8][26]. To determine the amount of activation caused by the advertisement stimulus, this is assessed and compared to the baseline. Below Table 4 describes an overview of fMRI in neuromarketing and its measures, usage, benefits, and limitation.

Table 4: Overview of fMRI in neuromarketing research

\begin{tabular}{|c|c|}
\hline Measures & Usage in testing \\
\hline $\begin{array}{l}\text { - encoding of the memory } \\
\text { - five sensory perceptions } \\
\text { - emotional valence } \\
\text { - desire } \\
\text { - belief } \\
\text { - loyalty towards brand } \\
\text { - preference towards brand } \\
\text { - recall of particular brand }\end{array}$ & $\begin{array}{l}\text { - new products } \\
\text { - commercial campaigns } \\
\text { - Advertisements } \\
\text { - recognizing the crucial flashes of an } \\
\text { commercials } \\
\text { - Designing the product packaging } \\
\text { - prices fixation } \\
\text { - brand re-positioning } \\
\text { - forecasting choices } \\
\text { - identifying wants } \\
\text { - sensory testing towards particular celebrity } \\
\text { endorsement for advertisement }\end{array}$ \\
\hline Benefits & Limitation \\
\hline $\begin{array}{l}\text { - high three-dimensional resolution, can see } \\
\text { brain structures [82],1-10 mm of deep structures } \\
\text { within a spatial resolution in the brain, as it } \\
\text { localizes brain activity variations [79] } \\
\text { - allows understanding of psychological } \\
\text { progressions in the brain [83] } \\
\text { - consumer selections and consumption } \\
\text { experience are known during localization of } \\
\text { neural process [79] } \\
\text { - available SSP which let both pre-processing } \\
\text { and statistical analysis, such as Brain Voyager } \\
\text { QX [84][85] and Statistical Parametric Mapping } \\
\text { (SPM5) [86][87][88] as the latter can rearrange } \\
\text { and precise pictures for motion, accomplish time } \\
\text { correction, or standardize data space with a } \\
\text { Gaussian model } \\
\text { - consistent and valid measure for reasoning and } \\
\text { emotional responses [76] } \\
\text { - it follows the metabolic activity in the brain } \\
\text { [77], therefore, changes in the flow of fluids and } \\
\text { changes in chemical composition can be detected } \\
\text { in the brain [76] } \\
\text { - non-invasive method }\end{array}$ & $\begin{array}{l}\text { - expensive if used in small sample sizes [75] } \\
\text { [79][81] } \\
\text { - person in observation must not shake his head } \\
\text { during the procedure [82] } \\
\text { - it captures dynamic changes as there is low } \\
\text { temporal resolution [79][80] } \\
\text { - uses inverse inference from brain activation to } \\
\text { brain function [83] } \\
\text { - Every process has a limited level of } \\
\text { complication [83] } \\
\text { - data analysis is very complicated [79][80][89] } \\
\text { - Chances of ethical barriers like privacy [76] }\end{array}$ \\
\hline
\end{tabular}

(3) Magneto Encephalography

Magneto Encephalography (MEG) is a non-invasive technique for studying cerebral activity. The magnetic field formed by brain activity is directly measured by MEG. The EEG, on the other hand, 
carries voltage variations. MEG can quantify the spatial and temporal intensity of brain activity across multiple brain areas [27]. MEG has a higher spatial resolution, but the benefit is outweighed by its high cost [8]. Below Table 5 describes an overview of MEG in neuromarketing and its measures, usage, benefits, and limitation.

Table 5: Overview of MEG in neuromarketing research

\begin{tabular}{|c|c|}
\hline Measures & Usage in testing \\
\hline $\begin{array}{l}\text { - attention } \\
\text { - perception } \\
\text { - memory }\end{array}$ & $\begin{array}{l}\text { - new products } \\
\text { - Commercial Ads } \\
\text { - Designing of packaging } \\
\text { - identifying wants } \\
\text { - sensory testing towards celebrity endorsing a } \\
\text { brand }\end{array}$ \\
\hline Benefits & Limitation \\
\hline $\begin{array}{l}\text { - High temporal resolution }[79][80][81] \\
\text { - non-invasive method } \\
\text { - consistent and valid measure for reasoning and } \\
\text { emotional responses [76] } \\
\text { - it follows the metabolic activity in the brain } \\
\text { [77], therefore, changes in the flow of fluids and } \\
\text { changes in chemical composition can be detected } \\
\text { in the brain [76] }\end{array}$ & $\begin{array}{l}\text { - to experiment the person, a room is required } \\
\text { which is free of earth's magnetic effect [82] } \\
\text { - it is better than EEG due to limited spatial } \\
\text { resolution [80][81] } \\
\text { - non-scalable [75] } \\
\text { - costly method and requires high equipment } \\
\text { costs [81] } \\
\text { - Chances of ethical barriers like privacy [76] } \\
\text { - data analysis is very complicated [80] }\end{array}$ \\
\hline
\end{tabular}

\section{(4) Positron Emission Tomography (PET)}

It is a method that is equivalent in efficiency and spatial resolution to fMRI. To acquire results, the procedure necessitates a brief exposure to radioactive particles. PET is very unwanted and less appealing for use as a neuromarketing technique due to the health risks connected with it [28]. Below Table 6 describes an overview of PET in neuromarketing and its measures, usage, benefits, and limitation.

Table 6: Overview of PET in neuromarketing research

\begin{tabular}{|c|c|}
\hline Measures & Usage in testing \\
\hline $\begin{array}{l}\text { - emotions Valence } \\
\text { - sensory perception }\end{array}$ & $\begin{array}{l}\text { - new products } \\
\text { - Commercial Ads } \\
\text { - Design of packaging }\end{array}$ \\
\hline Benefits & Limitation \\
\hline $\begin{array}{l}\text { - spatial resolution is very high [82] } \\
\text { - consistent and valid measure for reasoning and } \\
\text { emotional responses [76] } \\
\text { - it follows the metabolic activity in the brain } \\
\text { [77], therefore, changes in the flow of fluids and } \\
\text { changes in chemical composition can be detected } \\
\text { in the brain [76] }\end{array}$ & $\begin{array}{l}\text { - radioactive material to obtain is difficult due to } \\
\text { its short life [82] } \\
\text { - temporal resolution is very poor [80] } \\
\text { - costly method } \\
\text { - Chances of ethical barriers like privacy [76] } \\
\text { - aggressive method as they use radioactive } \\
\text { contrast [80] }\end{array}$ \\
\hline
\end{tabular}

(5) Eye Tracking

Eye-tracking is used to determine the main focus of a user's visual attention, their response to visual stimuli, gaze patterns, attention span, and pupil changes. The biggest benefit is the equipment's portability. The main drawback is the lack of emotional associations with various parts of the brain. Eye-tracking measures the amount of time spent concentrating, the item focused, frequency of observation, and pupil behaviour in response to stimulus [29]. Both fixed and interrupted eye movement is detected by the eye-tracking system. Below Table 7 describes an overview of eye tracking in neuromarketing and its measures, usage, benefits, and limitation 
Table 7: Overview of eye tracking in neuromarketing research

\begin{tabular}{|c|c|}
\hline Measures & Usage in testing \\
\hline $\begin{array}{l}\text { - pictorial fixation } \\
\text { - exploration } \\
\text { - identifying the pattern of movement of the eye } \\
\text { - spatial resolution } \\
\text { - enthusiasm } \\
\text { - attention }\end{array}$ & $\begin{array}{l}\text { - Websites and effectiveness of user-interface } \\
\text { - Experience in store } \\
\text { - Design of the packaging } \\
\text { - Commercial Ads } \\
\text { - Commercial Prints } \\
\text { - Consumer Perception } \\
\text { - Identifying the order of perceptions of stimulus } \\
\text { that is which events perceived first and last or } \\
\text { remain unnoticed } \\
\text { - shelf layout in store } \\
\text { - product placement in store }\end{array}$ \\
\hline Benefits & Limitation \\
\hline $\begin{array}{l}\text { - identifying the blink rate speed and pupil } \\
\text { dilation to know information on connection in } \\
\text { seeing an images with the degree of enthusiasm } \\
\text { [82] } \\
\text { - portable [75] } \\
\text { - spatial attention can be detected [77] } \\
\text { - non-invasive method }\end{array}$ & $\begin{array}{l}\text { - Equipment costs is more which includes the } \\
\text { cost of eye-tracker and technical support systems } \\
\text { [79] } \\
\text { - Not reliable [76] } \\
\text { - Eye conditions of the subject will decide the } \\
\text { results [76] }\end{array}$ \\
\hline
\end{tabular}

\section{(6) Facial Recognition or Electromyography}

It identifies a person's numerous facial expressions, which indicate his or her mental state. Electrodes linked to the lips measure minute facial muscle movements that are invisible to the naked eye. The electrodes are implanted in the mouth on the zygomaticus major and minor muscles, as well as the orbicularis and occipitofrontal muscles. Happiness, apathy, sorrow, and pain are among the emotions discovered by this approach [30]. The double meaning of certain emotions and inhibition of facial movements and are two drawbacks of this strategy [31]. Below Table 8 describes an overview of EMG in neuromarketing and its measures, usage, benefits, and limitation.

Table 8: Overview of EMG in neuromarketing research

\begin{tabular}{|c|c|}
\hline Measures & Usage in testing \\
\hline $\begin{array}{l}\text { - emotional valence } \\
\text { - being Social }\end{array}$ & $\begin{array}{l}\text { - consumer perception to commercials } \\
\text { - recall to particular brand }\end{array}$ \\
\hline Benefits & Limitation \\
\hline $\begin{array}{l}\text { - conscious and unconscious movements of the } \\
\text { face can be known } \\
\text { - Positive or negative emotions can be detected } \\
\text { [89] } \\
\text { - precise } \\
\text { - accessible software to eliminate artifacts }\end{array}$ & $\begin{array}{l}\text { - artifacts frequency is very low if the signal is } \\
\text { not filtered } \\
\text { - equipment is very costs [79] } \\
\text { - emotional state of a human under different } \\
\text { situation involves of a combination of basic } \\
\text { emotions therefore, may EMG response patterns } \\
\text { will be an outcome of function of such emotional } \\
\text { conditions [91] }\end{array}$ \\
\hline
\end{tabular}

\section{(7) Cardiovascular Parameters}

Variations in cardiovascular measures like heart rate and blood pressure may also be utilized to identify a customer's reaction to a product or a product campaign. The time it takes for a pulse to transition and the patterns of heartbeats can be used to determine a customer's attention span on a certain task [32]. 


\section{(8) Galvanic Skin Response}

Several human emotions, including fear, happiness, rage, worry, curiosity, and apathy produce measurable sensations on the hand. Human hands are monitored to know the stimulus produced by the neurological reaction, by which the data collected can be used for the purpose of marketing [33].

\section{(9) The Transcranial Magnetic Stimulation}

Transcranial Magnetic Stimulation (TMS) works by regulating cerebral activity by electromagnetic induction. There are two types of electric impulses used in transcranial magnetic stimulation: high and low frequency. A cortical region of interest can be temporarily activated and deactivated using this approach. The procedure cannot go beyond the neocortex which is a shortcoming of this methodology [34]. Below Table 9 describes an overview of TMS in neuromarketing and its measures, usage, benefits, and limitation.

Table 9: Overview of TMS in neuromarketing research

\begin{tabular}{|c|c|}
\hline Measures & Usage in testing \\
\hline $\begin{array}{l}\text { - attention } \\
\text { - perception } \\
\text { - consumer behaviour }\end{array}$ & $\begin{array}{l}\text { - New products } \\
\text { - Commercial Ads } \\
\text { - Design the package } \\
\text { - Sensory testing }\end{array}$ \\
\hline Benefits & Limitation \\
\hline $\begin{array}{l}\text { - portable } \\
\text { - Consumer behaviour can be known after some } \\
\text { alteration of brain activity [79] } \\
\text { - its effects are measured indirectly by the use of } \\
\text { behavioural responses [77] }\end{array}$ & $\begin{array}{l}\text { - expensive method [79] } \\
\text { - ethical challenges } \\
\text { - brain structures deeply cannot be stimulated } \\
\text { directly }\end{array}$ \\
\hline
\end{tabular}

\section{THE CONSUMERS BRAIN :}

Traditional methods have failed poorly for a long time. To determine the performance of a product campaign, market researchers have primarily relied on input from focus groups via surveys and interviews. The introduction of neuroimaging methods has opened up new and interesting methodological possibilities. Neuromarketing methods are largely used to determine the subconscious influence of advertising on a client. They will be able to properly anticipate the success or failure of advertising.

\section{APPLICATIONS OF NEUROMARKETING :}

Neuromarketing is largely used to determine the preferences of customers. Most important factor in marketing is influencing the customer to buy the product by giving the information about the product and making one know its value for use [35][36].

Product appearance and emotional connect in commercials helps in establishing trust, value and recognition, according to a well-established psychological truth in marketing. As a result, customer preferences and purchase decisions will be influenced. Advertisements that elicit comforting and soothing feelings elicit a sense of identity and activate reward regions in the customer's brain [13]. Advertising businesses can use neuromarketing to detect subsets of commercials, such as graphics, sound effects, and slogans to create more successful ads. Neuromarketing helps to better understand consumer preferences and choices before developing an advertising [11].

\section{BENEFITS OF NEUROMARKETING :}

Neuromarketing has served lot of benefits to the marketers as it helps in creating a better knowledge of the brain of the potential consumer's and positively influences their decision-making process [5][10][13][37]. Most of the consumer groups and allies are using this concept. Socio- demographic profile of the consumers such as their age, ethnicity, gender, residing place, and socio-economic limitations can all be used to divide the cohorts. This will lead to more accurate predictions of customer behaviour and more targeted marketing [38]. Table 10 lists numerous instances of neuromarketing and their modes of operation. 
Table 10: Exhibits the various Neuromarketing strategies, their impact, and their influence on customers.

\begin{tabular}{|c|c|c|c|}
\hline $\begin{array}{l}\text { Sr. } \\
\text { no. }\end{array}$ & $\begin{array}{c}\text { Neuromarketing } \\
\text { Strategy }\end{array}$ & Impact & Influence on Customers \\
\hline \multirow{3}{*}{1.} & \multirow{3}{*}{ Sound and colour } & \multirow{3}{*}{$\begin{array}{l}\text { The } \\
\text { immediate } \\
\text { effect on the } \\
\text { ones' brain }\end{array}$} & $\begin{array}{l}\text { People unconsciously pay attention to dark items when } \\
\text { they hear powerful bass. }\end{array}$ \\
\hline & & & $\begin{array}{l}\text { Music in a higher frequency range draws the listener's } \\
\text { attention to light objects. }\end{array}$ \\
\hline & & & $\begin{array}{c}\text { When compared to black, white draws more attention } \\
\text { from the people. }\end{array}$ \\
\hline \multirow[b]{2}{*}{2.} & \multirow{2}{*}{$\begin{array}{l}\text { The most } \\
\text { effective method } \\
\text { is to use scarcity } \\
\text { as a selling point } \\
\quad \text { in ads }\end{array}$} & \multirow{2}{*}{$\begin{array}{l}\text { Using ads to } \\
\text { influence } \\
\text { people }\end{array}$} & $\begin{array}{l}\text { Words, like buy the new publication now and be sure } \\
\text { not to miss the new publication are frames which helps } \\
\text { in gain, whereas loss making phrases like, be sure not to } \\
\text { miss out the new release will lead to loss. }\end{array}$ \\
\hline & & & $\begin{array}{l}\text { Individuals with strong desire preferring originality like } \\
\text { to hear what they will lose if they do not purchase the } \\
\text { goods, whereas those with a low desire for originality } \\
\text { prefer to listen to what they would gain by purchasing } \\
\text { it. }\end{array}$ \\
\hline \multirow[t]{2}{*}{3.} & \multirow{2}{*}{$\begin{array}{l}\text { Using subliminal } \\
\text { incentives to get } \\
\text { customers to buy } \\
\text { something online }\end{array}$} & \multirow{2}{*}{$\begin{array}{l}\text { Customers } \\
\text { who are } \\
\text { rewarded } \\
\text { are more } \\
\text { likely to } \\
\text { return }\end{array}$} & $\begin{array}{c}\text { Shops emphasize delayed benefits, such as a set number } \\
\text { of points earned with each transaction that may be } \\
\text { turned into store credit at a later date. }\end{array}$ \\
\hline & & & $\begin{array}{l}\text { Short-term benefits keep people on track while they } \\
\text { work toward long-term objectives. }\end{array}$ \\
\hline \multirow[b]{2}{*}{4.} & \multirow[b]{2}{*}{$\begin{array}{l}\text { Making the } \\
\text { product design } \\
\text { process more } \\
\text { efficient }\end{array}$} & \multirow{2}{*}{$\begin{array}{l}\text { Providing } \\
\text { the most } \\
\text { innovative } \\
\text { and one-of- } \\
\text { a-kind } \\
\text { packaging } \\
\text { alternatives }\end{array}$} & $\begin{array}{l}\text { A comparison of several packing choices for various } \\
\text { items. }\end{array}$ \\
\hline & & & $\begin{array}{l}\text { Hyundai and Volvo and utilized similar techniques to } \\
\text { determine which aspects of new car models appealed to } \\
\text { customers. }\end{array}$ \\
\hline \multirow[b]{2}{*}{5.} & \multirow[b]{2}{*}{$\begin{array}{l}\text { Making a multi- } \\
\text { sensory } \\
\text { misalignment }\end{array}$} & \multirow{2}{*}{$\begin{array}{l}\text { Products } \\
\text { and } \\
\text { packaging } \\
\text { that alter the } \\
\text { appearance } \\
\text { of the } \\
\text { material }\end{array}$} & $\begin{array}{c}\text { Consumers are stimulated in multiple ways by } \\
\text { successful brands. }\end{array}$ \\
\hline & & & $\begin{array}{l}\text { This implies they provide a brand experience that } \\
\text { includes more than simply visual components, such as } \\
\text { fragrance and taste. A mismatch occurs when two } \\
\text { sensory stimuli do not match. }\end{array}$ \\
\hline 6. & $\begin{array}{l}\text { Using } \\
\text { neuroscience to } \\
\text { predict future } \\
\text { success }\end{array}$ & $\begin{array}{l}\text { Having an } \\
\text { impact on a } \\
\text { product's } \\
\text { commercial } \\
\text { success } \\
\end{array}$ & $\begin{array}{l}\text { Time management, Market capitalizing, money, and } \\
\text { manpower management are all influenced. }\end{array}$ \\
\hline
\end{tabular}

\section{ADVANTAGES OF NEUROMARKETING :}

The term neuromarketing refers to the use of behavioural neuroscience in marketing. Neuromarketing techniques uncover stimuli and indications that show client behaviour that isn't visible to the naked eye [38]. Product design, successful advertising, and brand creation all benefit from neuromarketing strategies [39]. Apart from the neurological reaction at the time of purchase, they aid in understanding a customer's complete shopping experience from the moment they enter a store until they depart. A fascinating application is a virtual store with 2D and 3D retail merchandise that simulates shopping in a physical store. Test clients are exposed to genuine marketing scenarios and their purchasing decisions 
are successfully analyzed.

\section{LIMITATIONS OF NEUROMARKETING :}

The absence of trustworthiness and reliability of the information extracted is a major problem of neuromarketing [2][4][8][11][13][15][40]. Neuroscience concept gained importance in recent past with a lot of research and application in a variety of disciplines. Presently, there are now just a few articles accessible from neuromarketing businesses and academia [4][17][15][42]. Furthermore, the findings of businesses have been publicized.

Marketing researchers, for example, can be persuaded or influenced [2][43]. The Differential processing of marketing stimuli may also be an outcome of the presence of varied time and place of receipt [11][42]. Emotional valence and their association to specific regions in brain are hotly debated [10][16]. The difficulty of designing new research, as well as the considerable cost and time involved are all significant drawbacks of neuromarketing.

\section{IMPACT OF NEUROMARKETING :}

Neuro-marketing is a collection of neuro-techniques, neuro methods, and neurotechnology that aids in the establishment of subconscious communication between a firm and its target market, as well as the intensification of product and service purchases. This approach has helped in increasing more customers [73]. Other impacts of neuromarketing are as follows:

\section{(1) Consumer Buying Behaviour}

An in-depth study of client purchasing behaviour is becoming increasingly desirable and helpful [16][44][94] as the number of things on the market expands. A person's brain screens information about ones' desire which influences to make a purchase. To reduce the cost, a marketer needs understand the consumer's decision-making process [5]. Neuromarketing helps in obtaining the information for marketers to create new items that alter client purchase behaviour [26].

\section{(2) Advertising}

Advertisements stimulate certain parts of the brain. Effective commercials engage the ventral striatum and ventromedial prefrontal cortex in the brain [7]. The influence of favorable facial expressions in commercials was positively recognized in the study [7]. Neuromarketing technologies can properly assess an advertisement's reaction and success on an individual level. Advertisements can alter the decision-making area of the brain's medial prefrontal cortex resulting in increased sales [45].

\section{(3) Pricing}

It is a crucial aspect that might impact a customer's purchase choice [42]. Setting the appropriate price for a output which may be in service or product is an important aspect of purchase decisions [46][92][93]. Fixing a product's pricing and its relationship to a customer's buying choice is the most difficult component of marketing [47][48]. Neuromarketing contributes marketers in fixing the price for a product or service accepted by in the customers. Therefore, the marketers will be modifying the product's pricing properly. Moreover, to locate areas of the brain stimulated by happiness or pain suitable brain scanning techniques can be employed.

\section{(4) New Product Development}

Neuromarketing methods are seen to be more suited for assessing product experience rather than product conceptualization and development [5]. Alternative approaches can be employed if valid inputs for the creation of a new product cannot be acquired. On the other hand, other research implies that the intrinsic information revealed by fMRI scan data can be exploited for pretesting and product creation [49]. As a result, neuromarketing may be used to evaluate new products and develop new ones. Analysis like SWOC (Strengths, Weaknesses, Opportunities, and Threats) can be done in case of developing new product in addition to neuromarketing.

\section{(5) Communication}

The customers verbal communication will not be impacted by neuromarketing measures since it can be rationally analyzed using conventional market research methods. Outside reaction in neuromarketing technique analyze facial expressions and body language [19]. Inside reflex measures like EEG or fMRI are accurate. Therefore, results obtained in neuromarketing approaches will not be very useful in communication.

(6) Distribution of Products

Neuromarketing approaches may be used to optimize product distribution, arrangement, and 
presentation on supermarket shelves and racks. It may be utilized to find the best and most effective product layout pattern for grabbing customers' attention [50]. The top-shelf example is a good illustration of decision-making. Customers provide higher ratings to products on the store's top shelves [51]. Customers are more likely to be drawn to products on the top shelves [52]. Eye-tracking and caps with EEG connected to clients' heads while shopping can be used to research shopper behaviour [53]. This approach may also be used to analyze online stores [54].

\section{(7) Decision-Making}

In neuromarketing, there are five phases of decision-making. This includes recognizing the problem, analyzing the available options, making a decision after evaluating the options, contemplating the probable implications of actions, and learning from the decision-making process in the future [55]. The fMRI neuromarketing approach analyses the decision-making process as a culmination of emotions [56]. The ventromedial prefrontal cortex and striatum brain areas are involved in the decision-making process, as shown by EEG and fMRI [57]. To some extent, the consumer decision-making process can also be altered [58][59].

\section{(8) Branding}

Customers usually seek to associate loyalty with their favourite companies. Customers' decisions are influenced by emotional attachment and bonding created by brands [60]. This demonstrates the value of brand connection and marketers should take advantage of the chance. Preferred brands had more brain activity than popular brands according to fMRI research [7][13][61][62][63]. Brands have engendered an intuitive and concealed fear that influences the product decision-making process [13]. The successful brands' effective usage of neuromarketing methods is seen in Table 11.

Table 11: Exhibits the examples of a company using Neuromarketing [74].

\begin{tabular}{|c|c|c|}
\hline $\begin{array}{l}\text { Company } \\
\text { Name }\end{array}$ & Industry & Purpose of Neuromarketing \\
\hline GMTV & Television & $\begin{array}{c}\text { Conduct research to inform advertisers how viewers' minds } \\
\text { behave in the morning. }\end{array}$ \\
\hline VIACOM & Media & Examine how people react to advertisements. \\
\hline HAKUHODO & Advertising & $\begin{array}{l}\text { Examine how people react to items, advertisements, brands, and } \\
\text { video content. }\end{array}$ \\
\hline PHD & $\begin{array}{c}\text { Media } \\
\text { Planning }\end{array}$ & Estimate the advertising's proportional efficacy. \\
\hline $\begin{array}{c}\text { Martin } \\
\text { Lindstrom } \\
\text { (Neuroscience) }\end{array}$ & Author & $\begin{array}{l}\text { All of the fMRI scans included in Lindstrom's book study were } \\
\text { designed and evaluated by Neuroscience. }\end{array}$ \\
\hline Yahoo & Media & Describes how people react to a television commercial. \\
\hline Hyundai & Automotive & $\begin{array}{l}\text { Determine how people respond when they see a sports } \\
\text { automobile. }\end{array}$ \\
\hline Microsoft & $\begin{array}{l}\text { Technology } \\
\text { oftware }\end{array}$ & $\begin{array}{l}\text { Recognizing the sentiments of surprise, satisfaction, and } \\
\text { irritation that people have when they engage with computers. }\end{array}$ \\
\hline eBay & $\begin{array}{l}\text { Online } \\
\text { auctions }\end{array}$ & $\begin{array}{l}\text { Adopted a marketing campaign based on neuromarketing } \\
\text { research. }\end{array}$ \\
\hline Frito-Lay & Food Sector & Manufacturing Goods, Commercial Campaigns and packaging \\
\hline $\begin{array}{c}\text { Walt Disney, } \\
\text { Chevron, } \\
\text { Google }\end{array}$ & $\begin{array}{l}\text { Research in } \\
\text { Neuromarketi } \\
\text { ng }\end{array}$ & Consulting \\
\hline $\begin{array}{l}\text { The channel } \\
\text { like weather } \\
\text { forecast }\end{array}$ & Television & Examine how people react to advertisements. \\
\hline $\begin{array}{l}\text { Daimler } \\
\text { Automotive }\end{array}$ & Automotive & $\begin{array}{l}\text { Examine how people react to different types of automobile } \\
\text { headlights. }\end{array}$ \\
\hline PepsiCo & Food & Advertising campaign and Single-serve container concept. \\
\hline Porsche & Automotive & Consumer reaction to a commercial. \\
\hline
\end{tabular}




\begin{tabular}{|c|c|c|}
\hline Facebook & $\begin{array}{c}\text { Social } \\
\text { Networking }\end{array}$ & $\begin{array}{c}\text { How to organize an ad campaign, how frequently a page should } \\
\text { publish. }\end{array}$ \\
\hline Coca Cola & Food & Effective product promotion. \\
\hline PayPal & $\begin{array}{c}\text { Digital } \\
\text { Transfer of } \\
\text { money }\end{array}$ & Advertisement highlights convenience and swiftness. \\
\hline Volvo & Automobile & Automobiles designing. \\
\hline $\begin{array}{c}\text { Microsoft } \\
\text { company }\end{array}$ & $\begin{array}{c}\text { Software } \\
\text { development }\end{array}$ & $\begin{array}{c}\text { The human brain's reaction to the company's information, } \\
\text { content and web site design was studied using EEG and eye- } \\
\text { tracking data. }\end{array}$ \\
\hline Budweiser & Food & Investigate advertisements that elicit a good emotional reaction. \\
\hline
\end{tabular}

\section{(9) Product Design}

Product design and presentation and are significant aspects of market research and marketing. As a result, minute details should be paid close attention to the product design and presentation. Neuromarketing technologies such as EEG and fMRI can aid in product creation [44]. Because the whole process occurs subconsciously in the brain. The nucleus acumens and the ventromedial prefrontal cortex area of the brain have been linked to decision-making [64].

\section{ETHICAL CONCERNS OF NEUROMARKETING :}

Several ethical considerations of neuromarketing research methodologies and procedures should be addressed. Some argue that this method is not suitable with the free will of a person. Marketers believe that producing variety of products in the market can influence a person to make a purchase. Therefore, Neuromarketing technology helps in understanding the behaviour of customers to make self-decision [26]. This concept makes the marketer to focus on profit making rather than consumer's needs. [22]. Therefore, it is in direct opposition to the approach of a customer-company relationship that comprises privacy policy terms [65]. The process of using the brain probes to distort the brain's decision-making process violates the law of human rights and gives rise to ethical glitches, necessitating the establishment of guidelines and regulations [4][10]. The protection to the individual's right is wedged by neuromarketing research and also the preservation of the customer's free will in decision making are two critical ethical considerations in neuromarketing [40]. Of late, industry norms and regulations are required to be framed to unnecessarily avoid the misuse and appropriate application of neuromarketing approaches to advance the customer purchasing experience [5][66]. However, besides the fact that neuromarketing offers huge benefits, there are still various underlying certain concerns of ethical issues and a acceptable customer-oriented atmosphere that needs to be further addressed.

\section{CHALLENGES OF NEUROMARKETING :}

It is difficult to influence a customers' decision-making process [22]. Neuromarketing also faces challenges in influencing the buyer's decision. Usage of modern technology in market research gives benefit but same time it removes buyers' free will. It will destroy the customer's rational thought process and replace it with human robots that are designed to respond to marketing stimuli. Humans can be turned into programmed buying robots that consume specified items and product selections in other wards [7][26][42]. Neuromarketing is fast gaining traction among businesses and turning to for help [7][67][68][69][70][71].

\section{IMMINENT OF NEUROMARKETING IN INDIA :}

The recent development in the field of neuromarketing in India is steadily progressing. The Boston consultancy group reveals that the percentage of the rich class people and elite class of people in India among the five household income groups would rise from $8 \%$ to $16 \%$ between 2016 and 2025, while in comparison to the poor class of people will fall from thirty one percent to sixteen percent. The rich and elite people will account for forty percent of the population, up from $27 \%$ now. With a population of more than 130 billion people, India is expected to overtake China as the world's largest consumer market shortly. From 2011 to 2017, India's Consumer Price Index CPI averaged 114.67 Index Points, with a high of 137.60 Index Points in November 2017. With a growth rate of roughly 7\%, the present 2.8 trillion \$ GDP (2018) is predicted to reach 4.6 trillion $\$$ by 2025 (Table 12). 
Table 12: Exhibits the economic sizes of the countries USA, China, and India on nominal \& Purchasing Power parity (PPP) scale [72].

\begin{tabular}{|c|c|c|c|c|c|c|}
\hline Sr. No & Country & $\mathbf{2 0 1 0}$ & $\mathbf{2 0 1 5}$ & $\mathbf{2 0 1 8}$ & $\mathbf{2 0 2 3}$ & $\mathbf{2 0 3 0}$ \\
\hline 1 & USA & 14964 & 18120 & 20412 & 24537 & 32996 \\
\hline 2 & China & 6066 & 11226 & 14092 & 21574 & 34338 \\
\hline 3 & India & 1708 & 2089 & 2848 & 4663 & 10133 \\
\hline
\end{tabular}

Note: The GDP of the economies of USA, China and India on the Nominal scale from $2010-2030$ in US Dollars (billions).

The Indian advertising business is worth over 693 billion rupees in 2018 (Table 13).

Table 13: Exhibits the expenditure details of Indian advertising in media (billion rupees) [72].

\begin{tabular}{|c|c|c|c|c|c|c|}
\hline Sr. No & Country & $\mathbf{2 0 1 0}$ & $\mathbf{2 0 1 5}$ & $\mathbf{2 0 1 8}$ & $\mathbf{2 0 2 3}$ & $\mathbf{2 0 3 0}$ \\
\hline 1 & USA & 14964 & 18036 & 20412 & 24537 & 30998 \\
\hline 2 & China & 12405 & 19695 & 25238 & 37067 & 54366 \\
\hline 3 & India & 5312 & 8003 & 10385 & 16785 & 26526 \\
\hline
\end{tabular}

Note: The GDP of the economies of the USA, China, and India on the (PPP) scale from $2010-2030$ in US Dollars (billions).

India is the second-fastest expanding market among the top ten nations, and it will account for the sixth-highest share of worldwide incremental ad spending in 2021. While India was rated ninth in global ad expenditure in 2019, it fell to tenth in 2020 and is expected to reclaim its ninth position this year [73]. Below Table 14 describes the Indian advertising expenditure in various media.

Table 14: Exhibits the expenditure in billion rupees of the Indian advertising in media [73].

\begin{tabular}{|l|c|c|c|c|c|c|}
\hline \multicolumn{1}{|c|}{ Medium } & $\mathbf{2 0 1 9}$ & $\mathbf{2 0 2 0}$ & $\mathbf{2 0 2 1 f}$ & $\begin{array}{c}\mathbf{2 0 1 5 - 1 9} \\
\text { CAGR }\end{array}$ & $\mathbf{2 0 2 0}$ vs 19 & $\mathbf{2 0 2 1 f}$ vs 20 \\
\hline TV & 35,458 & 30,436 & 35,914 & $11 \%$ & $-14 \%$ & $18 \%$ \\
\hline Digital & 22,057 & 21,726 & 27,700 & $34 \%$ & $-2 \%$ & $28 \%$ \\
\hline Print & 18,164 & 10,350 & 12,731 & $1 \%$ & $-43 \%$ & $23 \%$ \\
\hline $\begin{array}{l}\text { OOH (Out } \\
\text { of Home) }\end{array}$ & 3,394 & 930 & 1,570 & $7 \%$ & $-73 \%$ & $69 \%$ \\
\hline Radio & 2,824 & 1,436 & 1,687 & $7 \%$ & $-49 \%$ & $17 \%$ \\
\hline Cinema & 1,008 & 175 & 520 & $25 \%$ & $-83 \%$ & $197 \%$ \\
\hline Total & $\mathbf{8 2 , 9 0 4}$ & $\mathbf{6 5 , 0 5 3}$ & $\mathbf{8 0 , 1 2 3}$ & $\mathbf{1 2 . 2} \%$ & $\mathbf{- 2 1 . 5} \%$ & $\mathbf{2 3 . 2} \%$ \\
\hline
\end{tabular}

All of the aforementioned factors lead to an upward trend in consumer spending, new product introductions, and market competitiveness. In this context, market researchers' favourable technique for assessing customer behaviour and mindset is neuromarketing.

\section{CONCLUSION :}

Neuromarketing concept offers interesting potential and new channels to further investigate and analyse in the field of marketing. However, the concept is still in its preliminary phase but has bright path for future [42]. Moreover, researchers in this field agree that the concept offers high benefits in marketing but at the same time faces lot of challenges which needs to be overcome by further research. In this competitive world, a marketer can gain high success if he uses neuromarketing concept to understand the consumers mindset. Thus, neuromarketing has a long go ahead for the future with the development in the field of science and technology.

\section{REFERENCES :}

[1] Karmarkar, Uma R (2011). Note on Neuromarketing. Harvard business school background Note, l(1), 512-031.

\section{Google Scholar X}

[2] Javor A, Koller M, Lee N, Chamberlain L, Ransmayr G. (2013). Neuromarketing and consumer neuroscience: Contributions to neurology. BMC Neurology, 13(1), 1-12.

Google Scholar $\chi^{\top}$ 
[3] Schneider T, Woolgar S. (2012). Technologies of ironic revelation: Enacting consumers in neuromarkets. Consumption Markets \& Culture, 15(2), 169-189.

Google Scholar X'

[4] Eser Z, Isin FB, Tolon M (2011). Perceptions of marketing academics, neurologists and marketing professionals about neuromarketing. Journal of Marketing Management, 27(7-8), 854-868.

Google Scholar X'

[5] Ariely D, Berns GS (2010). Neuromarketing: The hope and hype of neuroimaging in business. Nat Rev Neurosci, 11(4), 284-292.

Google Scholar $X^{7}$

[6] Calvert GA, Thensen T. (2004). Multisensory integration: Methodological approaches and emerging principles in the human brain. J Physoil, 98(13), 191-205.

Google ScholarX

[7] Kenning P, Linzmajer M. (2011). Consumer neuroscience: An overview of an emerging discipline with implications for consumer policy. Journal für Verbraucherschutz und Lebensmittelsicherheit, 6(1), 111-125.

Google Scholar $x^{7}$

[8] Morin C (2011). Neuromarketing: The new science of consumer behaviour. Society, 48(2), 131135 .

Google Scholar $\chi$

[9] Pradeep AK (2010). The buying brain: Secrets for selling to the subconscious mind. John Wiley \& Sons.

Google Scholar $\not 7$

[10] Senior C, Lee N (2008). Editorial: A manifesto for neuromarketing science. J Consumer Behav 7(4-5), 263-271.

Google Scholar $\chi^{7}$

[11] Fugate DL (2007). Neuromarketing: A layman's look at neuroscience and its potential application to marketing practice. Journal of Consumer Marketing, 24(7), 385-394.

\section{Google Scholar X'}

[12] Ohme R, Matukin M (2012). A small frog that makes a big difference: Brain wave testing of TV advertisements. IEEE Pulse, 3(3), 28-33.

Google Scholar $X$

[13] Hubert M, Kenning P (2008). A current overview of consumer neuroscience. J Consumer Behav, 7(4-5), 272-292.

Google Scholar $x^{\top}$

[14] Garcia JR, Saad G (2008). Evolutionary neuromarketing: Darwinizing the neuroimaging paradigm for consumer behaviour. J Consumer Behav, 7(4-5), 397-414.

Google Scholar $\chi^{7}$

[15] Fisher CE, Chin L, Klitzman R (2010). Defining neuromarketing: Practices and professional challenges. Harvard Review of Psychiatry, 18(4), 230-237.

Google Scholar X

[16] Butler MJ (2008). Neuromarketing and the perception of knowledge. J Consumer Behav, 7(4-5), 415-419.

Google Scholar $X^{\top}$ 
[17] Fugate DL (2008). Marketing services more effectively with neuromarketing research: A look into the future. Journal of Services Marketing, 22(2), 170-173.

Google Scholar 7

[18] Orzán G, Zara IA, Purcarea VL (2012). Neuromarketing techniques in pharmaceutical drugs advertising. A discussion and agenda for future research. J Med Life, 5(4), 428-432.

Google Scholar $X^{7}$

[19] Postma (2013) Anatomy of the Temptation. Neuromarketing - Neuromarketing successful to fit. pp 1-248.

Google Scholar $x^{7}$

[20] Leonard D, Rayport JF (1997). Spark innovation through empathic design. Harvard business review, 75(1), 102-115.

Google Scholar ${ }^{7}$

[21] Camerer C, Loewenstein G, Prelec D (2005). Neuroeconomics: How neuroscience can inform economics. Journal of economic Literature, 43(1), 9-64.

Google Scholar $\not^{\top}$

[22] Madan CR (2010). Neuromarketing: The next step in market research? Eureka, 1(1), 34-42. Google Scholar ${ }^{7}$

[23] Dimoka A, Banker RD, Benbasat I, Davis FD, Dennis AR, et al. (2012). On the use of neurophysiological tools in IS research: Developing a research agenda for neurois. MIS Quarterly, 36(3), 679-702.

Google Scholar $\overline{ }$

[24] Vecchiato G, Kong W, Maglione A, Wei D (2012). Understanding the impact of TV commercials: Electrical neuroimaging. IEEE Pulse, 3(3), 42-47.

Google Scholar $X^{\top}$

[25] Raichle ME, Mintun MA (2006). Brain work and brain imaging. Ann Rev Neurosci, 29(1), 449476.

Google Scholar $x^{\top}$

[26] Wilson R, Gaines J, Hill RP (2008). Neuromarketing and consumer free will. Journal of Consumer Affairs, 42(3), 389-410.

Google Scholar $x^{\top}$

[27] Miller M, Bentsen T, Clendenning D. D, Harris S, Speert D. (2008). Brain facts: A primer on the brain and nervous system, (6 ${ }^{\text {th }}$ edn). Society for Neuroscience, Washington. pp 76-80. Retrieved on 01-01-2022 from https://mpfi.org/wp-content/uploads/2019/04/ Brain_Facts_BookHigh $\underline{\text { Res1.pdf }}$

Google Scholar $x^{7}$

[28] Lin C H, Tuan H. P., Chiu Y. C. (2010). Medial frontal activity in brand loyal consumers: A behaviour and near-infrared ray study. Journal of Neuroscience, Psychology and Economics, 3(2), 59-73.

Google Scholar 7

[29] Nenad D. H. (2011). Emotional marketing: Eye-tracking and brain measuring: Using neuromarketing to sell newspapers. Editor \& Publisher, 144(1), 7-8.

Google Scholar $\not 7$

[30] Melillo W. (2006). Inside the consumer mind: What neuroscience can tell us about marketing. Adweek 47(3), 54-79. Retrieved on 1-1-2022 https://www.adweek.com/brand-marketing/insideconsumer-mind-83549/ 
Google Scholar $X^{\top}$

[31] Peterson, C. K. (2009). Electroencephalographic Methods in social and personality psychology. In: Harmon-Jones E, Jennifer SB (Eds.), Methods in Social neuroscience. TG Press, Guilford Publications, New York, USA, pp. 170-197.

Google Scholar X

[32] Lindstrom M. (2010). Buyology: Truth and lies about why we buy. Random House Digital. Pp 8285.

Google Scholar $\not^{\top}$

[33] Banks S. J, Bellerose J, Douglas D, Jones-Gotman M (2012). Bilateral skin conductance responses to emotional faces. Appl Psychophysiol Biofeedback, 37(3), 145-152.

Google Scholar $x^{\top}$

[34] Zurawicki L (2010). Neuromarketing: Exploring the brain of the consumer. Springer-Verlag Berlin Heidelberg, New York, USA. pp 1-287.

Google Scholar X

[35] Lee N. J, Senior C, Butler M. J., Fuchs R. (2009). The feasibility of neuroimaging methods in marketing research. Nature precedings. pp 1-1.

Google Scholar $\chi^{\top}$

[36] Fisher CE, Chin L, Klitzman R (2010). Defining neuromarketing: Practices and professional challenges. Harv Rev Psychiatry, 18(4), 230-237.

Google Scholar X

[37] Tusche A, Bode S, Haynes JD (2010). Neural responses to unattended products predict later consumer choices. J Neurosci, 30(23), 8024-8031.

Google Scholar $\chi^{7}$

[38] Venkatraman V, Clithero J. A, Fitzsimons GJ, Huettel S. A. (2012) New scanner data for brand marketers: How neuroscience can help better understand differences in brand preferences. $J$ Consumer Psycho, 22(1): 143-153.

Google Scholar ${ }^{7}$

[39] Belden SRA (2008). Science is Culture: Neuroeconomics and neuromarketing. Practical applications and ethical concerns. J Mind Theory, 1(2), 249-258.

Google Scholar $x^{\top}$

[40] Murphy E. R., Illes J, Reiner, P. B. (2008). Neuroethics of neuromarketing. J Consumer Behav, 7(4-5), 293-302.

Google Scholar 7

[41] Perrachione TK, Perrachione JR (2008). Brains and brands: Developing mutually informative research in neuroscience and marketing. J Consumer Behav, 7(4-5), 303-318.

Google Scholar X

[42] Lee N, Broderick A. J., Chamberlain L (2007). What is 'neuromarketing'? A discussion and agenda for future research. Int J Psychophysiol, 63(2), 199-204.

Google Scholar $\chi^{7}$

[43] Marci C. D. (2008). Minding the gap: The evolving relationships between affective neuroscience and advertising research. International Journal of Advertising, 27(3), 473-475.

Google Scholar $x^{\top}$

[44] Gang DJ, Lin W, Qi Z, Yan LL (2012). Neuromarketing: Marketing through Science. International Joint Conference, 285-289. 
Google Scholar $X^{\top}$

[45] Cranston R. E. (2004). Neuromarketing: Unethical advertising? The Centre for Bioethics and human Dignity. http://www. cbhd. org/resources/biotech/cranston_2004-02-13.html, 02-13. Google Scholar $x^{\top}$

[46] Simon H, Dolan R. J. (1998). Price Customization. Marketing Management, 7(3), 11-17. Google Scholar X'

[47] Vanhuele M, Drèze X (2002). Measuring the price knowledge shoppers bring to the store. Journal of Marketing, 66(4), 72-85.

Google Scholar $x^{7}$

[48] Evanschitzky H, Kenning P, Vogel V (2004). Consumer price knowledge in the German retail market. Journal of Product and Brand Management, 13(6), 390-405.

Google Scholar $\chi^{\top}$

[49] Calvert G. A, Brammer M. J. (2012). Predicting consumer behaviour: Using novel mind-reading approaches. IEEE Pulse, 3(3), 38-41.

Google Scholar $\nearrow^{\top}$

[50] Ailawadi K. L., Keller K. L. (2004). Understanding retail branding: Conceptual insights and research priorities. Journal of Retailing, 80(4), 331-342.

Google Scholar $x^{\nearrow}$

[51] Chandon P, Hutchinson J W, Bradlow E T, Young S H (2009). Does in-store marketing work? Effects of the number and position of shelf facings on brand attention and evaluation at the point of purchase. Journal of Marketing, 73(6), 1-17.

Google Scholar X

[52] Pieters R, Warlop L. (1999). Visual attention during brand choice: The impact of time pressure and task motivation. International Journal of Research in Marketing, 16(1), 1-16.

Google Scholar $x^{7}$

[53] Plassmann H, Ramsøy T. Z, Milosavljevic M. (2012). Branding the brain: A critical review and outlook. Journal of Consumer Psychology, 22(1), 18-36.

Google Scholar X

[54] Dreze X, Hussherr F. X (2003). Internet advertising: Is anybody watching? Journal of Interactive Marketing, 17(4), 8-23.

Google Scholar $\chi^{\top}$

[55] Rangel A, Camerer C, Montague P. R. (2008). A framework for studying the neurobiology of value- based decision making. Nature Reviews Neuroscience, 9(7), 545-556.

Google Scholar X

[56] Plassmann H, Ramsøy T. Z, Milosavljevic M. (2012). Branding the brain: A critical review and outlook. J Consumer Psychol, 22(1), 18-36.

Google Scholar X

[57] Peelen M. V, Li F. F, Kastner S. (2009). Neural mechanisms of rapid natural scene categorization in human visual cortex. Nature, 460(7251), 94-97.

Google Scholar X'

[58] Vohs K D, Schooler J W (2008). The value of believing in free will: Encouraging a belief in determinism increases cheating. Psychol Sci, 19(6), 49-54.

Google Scholar $x^{7}$

[59] Montague R (2008). Free will. Current Biology, 18(4), 584-585. 
Google Scholar X

[60] Bechara A, Damasio A. R (2005). The somatic marker hypothesis: A neural theory of economic decision. Games and Economic Behaviour, 52(2), 336-372.

Google Scholar X

[61] McClure S M, Li J, Tomlin D, Cypert K S, Montague L M, et al. (2004). Neural correlates of behavioural preference for culturally familiar drinks. Neuron, 44(2), 379-387.

Google Scholar $X^{7}$

[62] Schaefer M, Berens H, Heinze H, Rotte M (2006). Neural correlates of culturally familiar brands of car manufacturers. Neuroimage, 31(2), 861865.

Google Scholar X

[63] Walter H, Abler B, Ciaramidaro A, Erk S (2005). Motivating forces of human actions: Neuroimaging reward and social interaction. Brain Res Bull, 67(1), 368-381.

Google Scholar $x^{7}$

[64] Reimann M, Zaichkowsky J, Neuhaus C, Bender T, Weber B (2010). Aesthetic package design: A behavioral, neural and psychological investigation. J Consumer Psychol, 20(4), 431-441.

Google Scholar $x^{7}$

[65] Illes J, Racine E (2005). Imaging or imagining? A neuroethics challenge informed by genetics. Am J Bioeth, 5(2), 5-18.

Google Scholar $x^{7}$

[66] Kumlehn M (2011). Consumer Neuroscience: Pricing research to gain and sustain a cutting edge competitive advantage by improving customer value and profitability. SSRN p. 83.

Google Scholar $x^{\top}$

[67] Reid A. (2006). MRI scanners can improve advertising effectiveness. Campaign. Retrieved on 2512-2021 from https://economictimes.indiatimes.com/mri-scanners-can-improve-advertisingeffectiveness/articleshow/1375463.cms?from $=$ mdr

[68] Page G. (2012). Scientific realism: What 'Neuromarketing' can and can't tell us about consumers. International Journal of Market Research, 54(2), 287-290.

Google Scholar ${ }^{7}$

[69] Kotler P, Keller KL (2006). Marketing Management. Prentice-Hall International, New Jersey, USA. 199(2), 80-96.

Google Scholar $X^{\top}$

[70] Flores, Jason, Arne B, Robert S (2014). Is Neuromarketing Ethical? Consumers Say Yes. Consumers Say No. Journal of Legal, Ethical and Regulatory Issues, 17(2), 77-91. Google Scholar X

[71] Calvert G. A., Brammer M. J. (2012). Predicting consumer behaviour: Using novel mind-reading approaches. IEEE Pulse, 3(3), 38-41.

Google Scholar X

[72] Zubko, T., Kovshova, I., \& Sydorenko, O. (2020). Prospective trends in neuromarketing tools of the food industry in view of digitalization. International Journal of Advanced Science and Technology, 29(8), 2574-2579.

Google Scholar $x^{7}$

[73] Indian adex to grow by Rs 15,000 crore in 2021, digital to take Rs 6,000 crore: GroupM's TYNY report https://bestmediainfo.com/2021/02/indian-adex-to-grow-by-rs-15-000-crore-in-2021digital-to-take-rs-6-000-crore-groupm-s-tyny-report/ retrieved on 12/11/2-2021. 
[74] Solomon, P. R. (2018). Neuromarketing: Applications, Challenges and Promises. Biomedical Journal of Scientific \& Technical Research, 12(2), 9136-9146.

Google Scholar $x^{\top}$

[75] O'Connel, B., Walden, S., Pohlmann, A. (2011). Marketing and Neuroscience. What Drives Customer Decisions? American Marketing Association, White Paper. pp 4-18.

Google Scholar X'

[76] Wang, Y. J. \& Minor, M. S. (2008). Validity, Reliability and Applicability of Psychophysiolgical Techniques in Marketing Research. Psychology \& Marketing, 25(2), 197-232.

Google Scholar $X^{\top}$

[77] Perrachione, T. K. \& Perrachione J. R. (2008). Brains and Brands: Developing Mutually Informative Research in Neuroscience and Marketing. Journal of Consumer Behaviour, 7(1), 303318.

\section{Google Scholar 7}

[78] Ohme, R., Matukin, M., Pacula-Lesniak, B. (2011). Biometric measures for interactive advertising research. Journal of Interactive Advertising, 11(2), 60-72.

Google Scholar X

[79] Plassmann, H., Ramsøy, T. Z., Milosavljevic, M. (2011). Faculty and Research Working Paper: Branding the Brain - A Critical Review. INSEAD The Business School of the World, 15.

Google Scholar ${ }^{\top}$

[80] Kenning, P., Plassmann, H., Ahlert, D. (2007). Applications of functional magnetic resonance imaging for market research. Qualitative Market Research: An International Journal, 10(2), 135152.

Google Scholar 7

[81] Ariely, D. \& Berns, G. (2010). Neuromarketing: the hope and hype of neuroimaging in business. Nature Reviews Neuroscience, 11(4), 284-292.

Google Scholar X

[82] Zurawicki, L. (2010). Neuromarketing, Exploring the Brain of the Consumer. (42-53). Berlin Heidelberg. Springer-Verlag.

Google Scholar X

[83] Reimann, M., Schilke, O., Weber, B., Neuhaus, C., Zaichkowsky, J. (2011). Functional Magnetic Resonance Imaging in Consumer Research: A Review and Application. Psychology \& Marketing Wiley Periodicals, 28(6), 608-637.

Google Scholar 7

[84] Levy, I., Lazzaro, S., Rutledge, R. B., Glimcher, P. W. (2011). Choice from Non-Choice: Predicting Consumer Preferences from Blood Oxygenation Level-Dependent Signals Obtained during Passive Viewing. The Journal of Neuroscience, 31(1), 118-125.

Google Scholar X

[85] Morris, J. D., Klahr, N. J., Shen, F., Villegas, J., Wright, P., He, G., Liu, Y. (2009). Mapping a Multidimensional Emotion in Response to Television Commercials. Human Brain Mapping. 30(1), 789-796.

Google Scholar $X^{7}$

[86] Falk, E. B., Rameson, L., Berkman, E. T., Liao, B., Kang, Y., Inagaki, T. K., Lieberman, M. D. (2009). The Neural Correlates of Persuasion: A Common Network across Cultures and Media. Journal of Cognitive Neuroscience, 22(11), 2447-2459.

$\underline{\text { Google Scholar } x^{7}}$ 
[87] Plassmann, H., Kenning, P., Ahlert, D. (2007). Why Companies Should Make Their Customers Happy: The Neural Correlates of Customer Loyalty. Advances in Consumer Research, 34(1), 735739.

Google Scholar 7

[88] Plassmann, H., O'Doherty, J., Shiv, B., Rangel, A. (2008). Marketing actions can modulate neural representations of experienced pleasantness. PNAS, 105(3), 1050-1054.

Google Scholar $x^{7}$

[89] Savoy, R. L. (2005). Experimental design in brain activation MRI: Cautionary tales. Brain Research Bulletin, 67(1), 361-367

Google Scholar ${ }^{\top}$

[90] Bolls, P. D., Lang, A., Potter, R.F. (2001). The effect of message valence and listener arousal on attention, memory and facial muscular responses to radio advertisements. Communication Research, 28(5), 627-651.

Google Scholar $x^{7}$

[91] van Boxtel, A. (2010). Facial EMG as a Tool for Inferring Affective States. Proceedings of Measuring Behavior, 7(1), 104-108.

Google Scholar X

[92] Bialkova, S. E., \& van Trijp, J. C. M. (2010). Is Eye tracking an effective experimental tool for capturing consumers attention?. In Measuring Behavior, 20(4), 498-498.

Google Scholar $\chi^{\top}$

[93] Frederick, D. P., \& Bhat, G. (2021). Review on Customer Perception Towards Online Food Delivery Services. IJCRT, 9(7), b301-b314.

Google Scholar X

[94] Frederick, D. P., \& Parappagoudar, S. K. (2021). A Descriptive Analysis on Sustainable Business Strategy of Online Food Service Industry. IRJMETS, 3(3), 545-554.

Google Scholar $X^{\top}$

$* * * * * * * * * *$ 